\title{
Spor Paydaşlarının Fairplay Kavramına İlişkin Metaforik Algıları
}

\section{Metaphoric Conceptualization of Fairplay by Sports Stakeholders}

\author{
${ }^{1}$ Mehmet İNAN \\ ${ }^{2}$ Fatih DERVENT \\ ${ }^{3}$ Buket KARADAĞ
}

${ }^{1}$ Marmara Üniversitesi, Atatürk Eğitim Fakültesi

${ }^{2}$ Marmara Üniversitesi, Spor Bilimleri Fakültesi

${ }^{3}$ İstanbul Aydın Üniversitesi, Eğitim Fakültesi

\section{Yazışma Adresi}

Corresponding Address:

Doç. Dr. Mehmet INAN

ORCID: 0000-0002-1823-3756

Marmara Üniversitesi, Atatürk Eğitim Fakültesi, Göztepe Kampüsü

E-posta: minan@marmara.edu.tr

\section{öz}

Bu araştırmanın amacı, spor paydaşlarının (antrenör, sporcu, öğretim elemanı, yönetici ve öğrenci) "fairplay" ifadesine ilişkin kavramların, metaforlar aracılığı ile ortaya çıkarılmasıdır. Katılımcılar 402 kişiden oluşmaktadır. Verilerin toplanabilmesi için her katılımcıya "Fairplay __ gibidir, çünkü___ cümlesini içeren bilgi formu verilmiş ve akıllarına gelen ilk metaforu gerekçesiyle yazarak boşlukları doldurmaları istenmiştir. Bu araştırmada karma araştırma yöntemi kullanılmıştır. Nitel veriler içerik analizi kullanılarak çözümlenmiş, nicel veriler ise betimsel istatistikler kullanılarak sunulmuştur. Elde edilen bulgularına göre katılımcılar 23 adet geçerli metafor üretmişlerdir. Bu metaforlar ortak özellikleri bakımından üç farklı kavramsal kategori altında toplanmıştır. Bunlar sırasıyla: "bir değer olarak fairplay", "sosyal etkileşim olarak fairplay" ve "bir hak olarak fairplay" kategorileridir. Analiz sonuçlarına göre fairplay ifadesi ile katılımcıların çoğunlukla değerler sisteminde yer alabilecek kavramlar ürettiği sonucu ortaya çıkmıştır. Ayrıca, fairplay ifadesinin uğraşı alanları ve cinsiyetlere göre farklı olarak algılandığı ve buna göre kavramlaştırıldığı belirlenmiştir. Metaforların fairplay kavramını anlamak için etkili bir araç olduğu söylenebilir.

Anahtar Kelimeler: Fairplay, Spor, Metafor

\section{ABSTRACT}

The purpose of this study was to examine the mataphoric conceptualization of fairplay by sports stakeholders Participants were 402 individuals from sport related professions such as coach, athlete, instructor, manager, and student. Participants were asked to reveal the single metaphor they had in their minds in terms of the concept of fairplay by the prompt "Fairplay is like because

A mixed research design was used in this study. Quantitative data were reported descriptively. 23 valid metaphors were analyzed by content analysis and 3 conceptual categories were identified. The conceptual categories were: "fairplay as a value", "fairplay as social interaction", and "fairplay as a right", respectively. Content analysis revealed that participants mostly used metaphors related to values in life. In addition, there were differences in conceptualization of fairplay according to profession and gender. Metaphors seem to be an effective tool to comprehend the concept of fairplay.

Key Words: Fairplay, Sport, Metaphor 


\section{GíRIŞ}

Metaforlar dünyayı anlama çabamızı ortaya koyar. Bu yüzden anlaşılmaya çalışılan yeni kavramları, daha önce bildiğimiz kavramlarla bağdaştırılarak zihnimizce tanımlanabilmeye çalışılır. Metaforlar bir kavramın sahip olduğu asıl anlamından daha fazlasını temsil ederler ve daha önce var olmayan anlamların oluşturulmasını sağlarlar (Thornborrow ve Wareing, 1998). Saban (2010) metaforların yeni bir şey ortaya koymadığını aslında var olan şeyleri başka bir açıdan görebilmemizi sağladığını belirtir. Mojtabai (2000) da zihnimizce henüz aydınlatılmamış kavramların metaforlarla anlaşılabileceği konusuna vurgu yapmıştır. Metaforlar, ilk kez deneyimlediğimiz ya da farkına vardığımız farklı kavramları eşleştirerek bu konuda bir anlayış geliştirebilmemizi mümkün kılar. Kövecses (2002) metaforlar sayesinde kavramların asıl anlamının değiştirilmeden zihnimiz ve kavramlar arasında bağlar kurabildiğimizi belirtmiştir.

Metaforlar üzerine yaptığı çalışmalarla birçok araştırmaya kaynak olmuş Lakoff ve Johnson (1980)'a göre kavramsal metaforlar düşüncelerimizi yapılandırırlar. Metaforlar sosyal ve kültürel değerlerden ortaya çıkar, ne düşünüyorsak metaforlar tarafından oluşturulur (Martinez, Sauleda ve Huber, 2001). Lakoff ve Johnson (1980) bir kültürün sahip olduğu en temel değerlerin, o kültürdeki temel kavramlar için kullanılan metaforik ifadelerle anlaşılabileceğini belirtmişlerdir. $\mathrm{Bu}$ ifadeden hareketle metaforların bir kelimeden daha fazla şey ifade ettiği söylenebilir.

Spor alanındaki kavramlar genelde benzetme yoluyla aktarıldığı için metafor oluşturmaya oldukça uygundur. Bu kavramların bazılarını (güç, kuvvet, zarafet, acizlik vb.) vurgulayan metaforlar günlük hayatımızda da sık sık kullanılmaktadır. "Aslan gibi kükremek”, "kartal gibi süzülmek”, "firtına gibi esmek”, "tazı gibi koşmak”, “ok gibi firlamak", "kuğu gibi dans etmek" ve "kaplumbağa gibi gitmek" bunlardan bazılarıdır ve bazı sportif aktivitelerde kültürel özelliklerden beslenilerek oluşturulmuş metaforlarla motivasyon amacıyla ya da hiciv amacıyla kullanılabilmektedir.

Alanyazın incelemesinde, yapılan çalışmaların metaforların farklı özelliklerine odaklanıyor olduğu dikkat çekmektedir. Clarke (2009) çalışmasında futbola ilişkin metaforları, zihinsel sorunlar yaşayan hastaların yaşadığı zorlukların üstesinden gelmek için kullanmıştır. Futbola ilişkin metaforların kişisel değerlendirme yapma firsatı vererek iyileştirici bir etki oluşturduğunu belirtmiştir. Bir başka çalışmada ise (Spander, Roy ve Mckeown, 2014) metaforların psiko-sosyal açıdan uyum sorunu yaşayan bireylere destek amaçlı olarak kullanılabileceği ortaya konulmuştur.

Sporcular kariyer basamaklarında ilerlerken çeşitli zorluklarla karşılaşmaktadırlar. Bu süreçte sporcuların yaşadığı psikolojik zorluklar üzerine yapılan bazı araştırmalarda, spor kariyeri boyunca değişen koşulların oluşturduğu sorunlarla başa çıkabilmek için metaforların kullanabileceği vurgulanmıştır (Triggs, Lafferty, Brown ve Tolley, 2011). Bu çalışmada, genç sporcular metaforları kullanarak duygu ve düşüncelerini açık bir şekilde ifade etme şansı bulmuş, iletişim becerilerini geliştirmiş ve böylelikle değişen koşullara yönelik anlam oluşturabilmişlerdir. Hanin ve Stambulova (2002) sporcuların kendi performanslarını nasıl algıladıklarını incelemek için yine metaforları kullanmışlardır. Elde edilen bulgular, sporcular tarafından kullanılan metaforların performans öncesi, esnası ve sonrasında değişim gösterdiğini ortaya koymuştur. Kellett (2002) ise antrenör ve sporcular arasındaki etkileşime yönelik kullanılan metaforları incelemiş ve katılımcıların sözü edilen etkileşimi tanımlarken savaş tabirlerini kullanmayı tercih ettiklerini belirlemiştir. Katılımcılar, antrenörleri generallere benzetilirken sporcuları asker olarak tanımlanmıştır.

Metaforlar, anlaşılmayan, zihinsel karmaşıklığa neden olan kavramı başka bir şeye benzeterek berraklaştırabilir. Beden eğitimi ve spor ortamlarında bir bilgi ya da becerinin ki bunlar kural, teknik, taktik, strateji gibi bilişsel ve devinişsel öğeler taşıyabilir, anlaşılabilmesi için de metaforlar kullanılabilir. Öğrencilerin yaşadığı özellikle zihinsel zorlukların, yanlış anlamaların ortadan kaldırılabilmesinde farklı formlardaki metaforlar, benzetmeler, örnekler büyük önem taşır (Grossman, 1990). Anlaşılmakta zorlanılan kavramın anahtar öğelerine yönelik olarak sunulan görsel 
betimlemeler öğrenci ve sporcuların anlam verme süreçlerini zenginleştirecektir. Örneğin, tek ayak denge pozisyonunu sergilemeye çalışan bir öğrenciye "leylek gibi dur" denmesi öğrencinin beceriyi zihninde resmetmesine katkı sağlayabilir. Futbolda ayak içi top kontrolü çalışan bir öğrenciye topu nasıl yumuşatması gerektiği "ayağının içinde yastık varmış gibi” ya da "topu bir yumurta gibi düşün" örnekleriyle anlatılabilir. Hentbolda dörde dört maç esnasında, taktiksel olarak derinlik ve genişlik kavramlarını anlamakta zorlanan öğrencilere hücum ederken "elmas şeklini al” denmesi verilebilecek bir başka örnektir.

Gassner (1999) metafor kullanımının öğretimin kalitesini arttırarak sportif becerilerin öğrenilmesine katkı sağladığını belirtmiştir. Bir beceri sergilenirken bilişsel, duyuşsal ve devinişsel tüm öğrenme alanlarının bütünleştirilebilmesi önem taşır bu bağlamda Gassner (1999) metaforların öğrencilerin motivasyonunu yükselttiğini ve öğrenilecek becerinin önceden zihinde resmedilmesini sağlayarak sportif performansı arttırdığını vurgulamıştır.

Metaforlar, beden eğitimi ve spor öğretiminde öğrenme kalitesinin yükseltilmesinden, sporcularda motivasyonun arttırılmasına, bilişsel karışıklıkların giderilmesinden sporcuların bireysel performanslarını tanımlamalarına kadar sporla ilişkili birçok kavramın anlamlandırılması için kullanılmaktadır. Spor kültürü içerisine giren önemli öğelerden biri olan fairplay kavramı da metaforlar yoluyla ele alınabilir. Fairplay, en basit ifadeyle temel insani değerlere karşı duyarlı olarak spor alanında yer alan diğer tüm paydaşlara karşı sorumlu ve hoşgörülü olmak olarak tanımlanabilir. Boixados ve Cruz (1995) geliştirdikleri fairplay tutum ölçeğinde, fairplay kavramının taşıdığı öğeleri; oyun kurallarına yönelik farkındalık ve saygı, rakiple doğru ilişkiler, herkes için aynı firsat ve koşulların korunması, her ne pahasına olursa olsun kazanma anlayışından kaçınma, zaferde ve yenilgide onurlu tutum sergileme ve elinden gelenin en iyisini yapma olarak sıralamışlardır. Sporcular bazen kazanma kaygısını o denli yoğun bir şekilde yaşarlar ki kendi performanslarından çok dış faktörlere (rakip, hakem, yönetici ve seyirciler) odaklanırlar. Bu durum etkin bir performans sergilemeleri önünde en büyük engeldir. Bu nedenle beden eğitimi ve spor öğretiminde fairplay kavramının önemi çoğu kez belirtilmiş̧ir. Öğrencilerin spor etkinliklerinde adil oyun bilinci kazanması konusunda öğretmenlerin kolaylaştırıcı rolü son beden eğitimi ve spor dersi programında da (Milli Eğitim Bakanlığı [MEB], 2017) vurgulanmaktadır.

Düşündüğümüz, deneyimlediğimiz birçok şeyin kaynağı aslında metaforlardır. Dolayısıyla düşüncelerimizi şekillendirir ve sonuç olarak davranışlarımızı belirlerler (Lakoff ve Johnson, 1980; Hardcastle, Yamamoto, Parkay ve Chan, 1985; Martinez ve diğ, 2001). Bu bağlamda fairplaye spor paydaşları tarafindan ne tür anlamlar yüklendiğini belirlemek önemli bir konu olarak karşımıza çıkmaktadır. Böylece soyut dolayısıyla anlamlandırılması hiç de kolay olmayan fairplay kavramının daha anlaşılır hale dönüştürülmesi, özümsenmesi ve böylece spor ortamlarına davranış olarak aktarılmasına katkı sağlayabileceği düşünülmektedir. Bu çalışmada metaforların anlam oluşturma sürecindeki etkisi dikkate alınarak, spor dünyasındaki farklı paydaşların fairplay kavramına yükledikleri anlamlar incelenmeye çalışılmıştır. Bu bağlamda cevap aranan araştırma soruları aşağıda sunulmuştur.

(1) Fairplay ifadesine ilişkin metaforik kavramlar nelerdir?

(2) Fairplay ifadesine ilişkin kullanılan metaforik kavramlar katılımcıların cinsiyetlerine ve uğraşlarına göre nasıldır?

\section{YÖNTEM}

Araştırmada, katılımcıların fairplay kavramına yönelik düşüncelerini ifade etmek amacıyla oluşturdukları metaforları belirlemede karma araştırma yöntemi kullanılmıştır. Karma yöntem, araştırmacının bir çalışmada nitel ve nicel yaklaşımları birleştirmesi olarak tanımlanır (Creswell, 2003). Elde edilen veriler araştırmanın ikinci problem cümlesine 
cevap verebilmek için aynı zamanda sayısallaştırılmış, frekans ve yüzde değerleri kullanılarak betimsel olarak sunulmuştur.

Katılımcılar: Araştırmanın veri toplama sürecine 431 kişi dâhil olmuştur. Ancak verilerin çözümlenmesi sürecinin ilk adımında belirlenen ölçütlere uygun olmayan 29 katılımcının verileri değerlendirmeye alınmadığından toplam katılımcı sayısı 402 olarak belirlenmiştir.

Tablo 1. Katılımcılara ait bilgiler

\begin{tabular}{ccccccc}
\hline & $\begin{array}{c}\text { Sporcu } \\
\boldsymbol{f}(\boldsymbol{\%})\end{array}$ & $\begin{array}{c}\text { Antrenör } \\
\boldsymbol{f}(\boldsymbol{\%})\end{array}$ & $\begin{array}{c}\text { Öğrenci } \\
\boldsymbol{f}(\boldsymbol{\%})\end{array}$ & $\begin{array}{c}\text { Öğretim Elemanı } \\
\boldsymbol{f}(\boldsymbol{\%})\end{array}$ & $\begin{array}{c}\text { Diğer } \\
\boldsymbol{f}(\boldsymbol{\%})\end{array}$ & $\begin{array}{c}\text { Toplam } \\
\boldsymbol{f}(\boldsymbol{\%})\end{array}$ \\
\hline Erkek & $50(18,0)$ & $72(26,0)$ & $36(13,0)$ & $83(30,0)$ & $36(13,0)$ & $277(68,9)$ \\
Kadın & $20(16,0)$ & $22(17,6)$ & $25(20,0)$ & $33(26,4)$ & $25(20,0)$ & $125(31,1)$ \\
\hline \multirow{2}{*}{ TOPLAM } & $70(17,4)$ & $94(23,4)$ & $61(15,2)$ & $116(28,8)$ & $61(15,2)$ & $402(100.0)$ \\
\hline
\end{tabular}

Tablo 1'e bakıldığında katılımcı grubunun \%17,4'ü elit ya da amatör düzeyde bireysel ya da takım sporlarından birinde resmi yarışma ve müsabakalara katılan ve bunun için düzenli antrenman yapan sporcular, \%23,4’ü yine elit ya da amatör düzeyde bireysel ya da takım sporlarından birinde aktif olarak çalışmakta olan antrenörler, \%15,2'si bir yükseköğrenim kurumunda, spor bilimleri alanında (beden eğitimi ve spor öğretmenliği, spor yöneticiliği, rekreasyon veya antrenörlük bölümleri) lisans, yüksek lisans ya da doktora düzeyinde öğrenim görmekte olan öğrenciler, \%28,8’i yine spor bilimleri alanında eğitim veren bir yükseköğrenim kurumunda çalışmakta olan öğretim elemanları ve \%15,2'si sporla ilişkili diğer sektörlerden kişiler oluşturmaktadır. Son grupta yer alan ve diğer olarak sınıflandırılan katılımcılar, verilerin toplandığı dönemde spor turizmi, spor organizasyonu ve spor malzemesi satışı gibi sporla ilişkili resmi veya devlet kurumlarında profesyonel olarak görev almakta olduklarını bildirmişlerdir. Katılımcıların tümü, eğitim ve çalışma hayatları dışında da sporla günlük olarak ilgilendiklerini belirtmişlerdir.

Veri Toplama Süreci: Yıldırım ve Şimşek’e (2011) göre metaforların odak noktası olduğu çalışmaların veri toplama süreci, açık uçlu sorulardan oluşan bireysel ya da odak grup görüşmelerle nitel veri toplanmasıyla benzerlik göstermektedir. Bununla birlikte metaforlar çalışılan olgunun derinlemesine anlaşılabilmesi için zengin bir imge sunar. $\mathrm{Bu}$ bağlamda katılımcılara öncelikle veri toplama aracı ile ilgili açıklayıcı bilgiler verilmiş ve kişisel bilgi formu sunulmuştur. Böylece kendilerinden yaş, cinsiyet, eğitim ve uğraşı alanı olmak üzere kişisel bilgileri toplanmıştır. Ardından, katılımcılara "Fairplay gibidir, çünkü " cümlesini içeren bir form sunulmuştur. İlk olarak, fairplay ifadesini nasıl kavramlaştırdıklarını belirleyebilmek için katılımcılardan fairplay ifadesini düşündüklerinde akıllarına gelen ilk metaforu cümledeki birinci boşluğa yazmaları istenmiştir. İkinci adımda ise kullandıkları metaforun konusu ve kaynağını belirtmek ayrıca tercih nedenlerini gerekçelendirmek için cümledeki ikinci boşluğu yazarak tamamlamaları beklenmiştir. Böylelikle, tercih edilen metaforların mantıksal tutarlığı irdelenmeye çalışılmıştır (Saban, 2010). Katılımcıların ilgili boşluklara kendi el yazılarıyla akıllarına gelen ilk metaforu ve bunu tercih etme gerekçelerini yazmalarıyla çalışmanın verileri elde edilmiştir.

Verilerin Çözümlenmesi: Araştırmadan elde edilen veriler sayısallaştırılarak frekans ve yüzde içeren tablolar ve grafikler kullanılarak sunulmuştur. Bununla birlikte nitel veriler içerik analizi ile çözümlenmiştir. İçerik analizi değerler, niyet, tutum ve biliş gibi bireysel ve toplumsal derin yapıların incelenmesinde kullanılabilir (Carley, 1993). İçerik analizi araştırmacılara nicel yöntemlerle anlaşılması kolay olmayan sosyo-biliş ve kavramsal yapıları inceleme firsatı verirken aynı zamanda sadece nitel yöntemle çalışılması zor olan büyük örneklemlerden veri elde edilmesine ve çözümlenmesine 
firsat vermektedir (Duriau, Reger ve Pfarrer, 2007). Karma araştırma yönteminin tercih edildiği bu araştırmada içerik analizinin kullanılmasının bir avantaj olduğu düşünülmektedir.

Buradaki temel amaç sayısal olarak ortaya konulan bulguların nitel alıntılarla desteklenerek katılımcıların sundukları açıklamalardaki örtük anlamların açık hale getirilmesidir. Böylece kodlama ve kavramsal kategorilere ayırma işlemi neticesinde metaforların anlam ve bağlamdan soyutlanmasının önüne geçilmiştir (Bilgin, 2014).

İçerik analiziyle insanların zihinlerinde oluşturdukları bilişsel şemaların araştırmacı tarafından anlaşılabileceği varsayımını taşımaktadır. Esasında kullanılan kelimelerin frekansları bilişsel odağın belirlenmesinde önemli bir unsur olarak kabul edilebilir (Huff, 1990). İçerik analiziyle veriler kavramsal kategoriler çatısı altında gruplanmış, oluşturulan örüntülerle bulgular yorumlanmaya çalışılmıştır (Yıldırım ve Şimşek, 2011).

Verilerin çözümlenmesinin ilk aşamasında, kullanılan her bir metafor ve gerekçesi çalışmanın araştırmacıları tarafından ayrı ayrı olarak incelenmiştir. İlk aşamada yapılan incelemeler sonrası bazı veriler (a) cümledeki boşluklardan en az birinin doldurulmamış olması, (b) metaforik bir ifade yerine tanım içeriyor olması (Örneğin; Fairplay dürüstçe oynamaktır.) ve (c) kullanılan metaforun mantıksal bir gerekçeyle desteklenmiyor olması durumunda (Örneğin; Çünkü dürüst olmayı severim.) sınıflama dışı bırakılmışlardır. Yukarıda sözü edilen gerekçeler nedeniyle 29 katılımcıya ait veriler çıkarılmış ve toplam 402 katılımcının verdiği cevaplar ile toplam 23 geçerli metafor ortaya çıkmıştır. İkinci aşamada, alfabetik olarak sıralanan geçerli 23 metafor, fairplay kavramının sahip olduğu özelliklere göre yine araştırmacılar tarafından ayrı ayrı olmak üzere incelenmiştir. Araştırmacılar, geçerli 23 metaforun gruplandırılabilmesi için üç kavramsal kategori teklifinde bulunmuşlardır. Araştırmacıların tamamı tarafından önerilen “değer”, “sosyal etkileşim” ve "hak" ortak kavramsal kategoriler olarak belirlenmiş ve metaforlar sözü edilen kavramsal kategoriler altında gruplanmıştır (Tablo 2). İkinci araştırma sorusuyla cevap aranan metaforik kavramların katılımcıların cinsiyetlerine ve uğraşlarına göre frekans ve yüzde değerleriyle grafikleştirilerek verilmiştir. İstatistiki olarak analizlerin yapılmasına uygun olmayan data söz konusu olduğu için (Alpar, 2006) sonuçlar yüzde ve frekans olarak sunulmuştur (Grafik 1; Grafik 2).

Güvenirliğin Sağlanması: Verilerin elde edilmesi ve çözümlenmesi sürecinde araştırmanın güvenirliğini sağlamak için iki yol izlenmiştir. Öncelikle, yukarıda sözü edildiği gibi araştırmacılar geçerli kodların ve kavramsal kategorilerin belirlenmesi sürecinde bağımsız hareket etmiş, bireysel olarak oluşturdukları listeler sonrasında birbirleriyle karşılaştırılmış, üzerlerine tartışılmış ve fikir birliğine varıldıktan sonra son ve kesin listeler oluşturulmuştur. Ardından, yine ayrı ayrı olmak üzere araştırmacılar, 23 metaforu kavramsal kategoriler ile ilişkilendirmişlerdir. Metafor- kavramsal kategori ilişki listeleri birbirleriyle kıyaslanmıştır. Kodlayıcılar arası güvenirlik yüzdesi, fikir birliğine varılan metafor sayısının (21) toplam metafor sayısına (23) bölünmesi, son olarak da 100 ile çarpılmasıyla elde edilmiştir. Bu hesaplama sonrasında kodlayıcılar arası güvenirlik yüzdesi \%91.3 olarak hesaplanmıştır ki bu oran \%80 olan kabul edilebilir yüzdenin üzerindedir (Miles \& Hubermans, 1994).

\section{BULGULAR}

Araştırmanın bu bölümünde, fairplay ifadesine yönelik kullanılan metaforları içeren üç kavramsal kategori cinsiyet ve uğraşı alanı değişkenlerine göre incelenmiş olup, sonuçlar grafiklerle açıklanmıştır. 


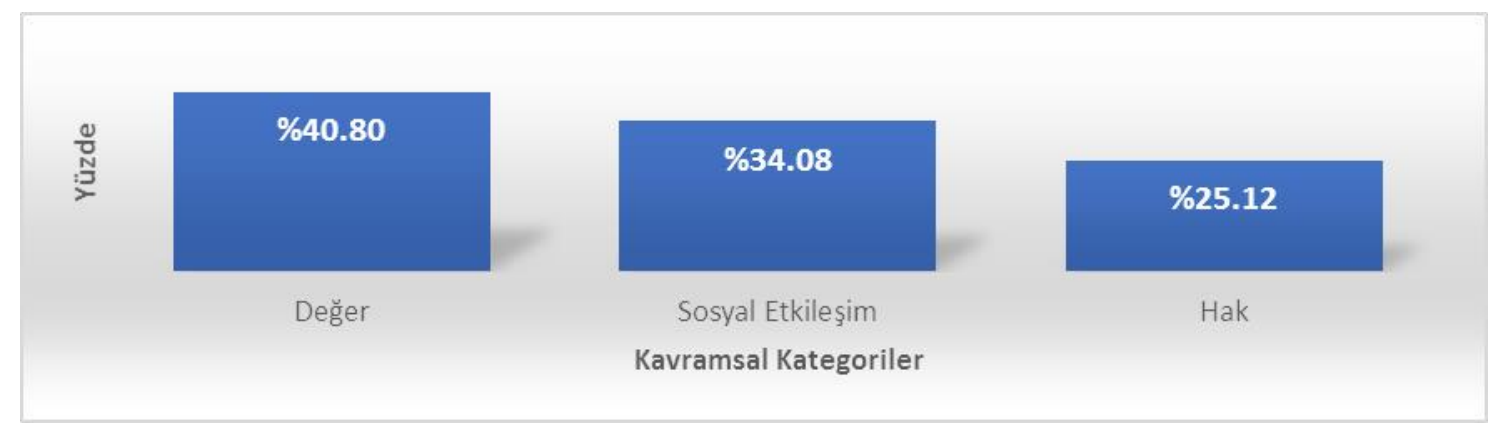

Grafik 1. Kavramsal kategorilere ait yüzdeler

Katılımcılar, fairplay ifadesini en çok “değer” kavramsal kategorisi ile ilişkilendirmişlerdir (\%40.80). Sırasıyla, “sosyal etkileşim” (\%34.08) ve "hak" (\%25.12) araştırmacılar tarafından atfedilen diğer kavramsal kategorilerdir. Kullanılan metaforlar ve gerekçelerini içeren alıntıların kime ait olduğunu belirtmek için gerekçelerin sonuna bazı bilgiler eklenmiştir. Cinsiyetleri belirtmeye yönelik erkek katılımcılar için E, kadın katılımcılar için K kısaltmaları kullanılmış ardından katılımcının uğraşı alanları yazılmıştır.

Fairplay ifadesini kavramlaştırmak için tercih edilen 23 metaforun yer aldığı üç kavramsal kategori (Tablo 2) betimsel istatistik kullanılarak yüzde ve frekans değerleriyle aktarılmış ve katılımcıların bu metaforları tercih etme gerekçelerini içeren ifadelere yer verilmiştir.

Tablo 2. Metaforlar ve ilişkilendirildikleri kavramsal kategoriler

\begin{tabular}{|c|c|c|c|c|c|c|c|c|}
\hline \multicolumn{3}{|c|}{ Değer olarak fairplay } & \multicolumn{3}{|c|}{ Sosyal etkileşim olarak fairplay } & \multicolumn{3}{|c|}{ Hak olarak fairplay } \\
\hline Metafor & Frekans & Yüzde & Metafor & Frekans & Yüzde & Metafor & Frekans & Yüzde \\
\hline Erdem & 42 & 25.61 & Dostluk & 58 & 42.34 & Kural & 58 & 57.43 \\
\hline Saygı & 39 & 23.78 & Yaşam & 18 & 13.14 & Adalet & 17 & 16.83 \\
\hline Nezaket & 18 & 10.98 & Birlik & 16 & 11.68 & Kanun & 13 & 12.87 \\
\hline İyi niyet & 17 & 10.37 & Aile & 9 & 6.57 & Eşitlik & 7 & 6.93 \\
\hline Dürüstlük & 14 & 8.54 & Barış & 9 & 6.57 & Bağımsızlık & 6 & 5.94 \\
\hline İnsanlık & 13 & 7.93 & Dayanışma & 9 & 6.57 & & & \\
\hline Ahlak & 13 & 7.93 & Paylaşım & 8 & 5.83 & & & \\
\hline Onur & 4 & 2.43 & $\begin{array}{l}\text { Meydan } \\
\text { Okuma }\end{array}$ & 5 & 3.65 & & & \\
\hline Hoşgörü & 4 & 2.43 & Yansitmak & 5 & 3.65 & & & \\
\hline TOPLAM & 164 & 100 & TOPLAM & 137 & 100 & TOPLAM & 101 & 100 \\
\hline
\end{tabular}

Bir değer olarak fairplay kavramsal kategorisi katılımcıların \% 40.8'i tarafından tercih edilmiş metaforları içermektedir. Bu katılımcıların \% 68'i erkek, \% 32'si kadındır. Geliştirilen metaforlar sırasıyla erdem (\%25.61), saygı (\%23.78), nezaket (\%10.98), iyi niyet (\%10.37), dürüstlük (\% 8.54), insanlık (\%7.93), ahlak (\%7.93), onur (\% 2.43) ve hoşgörü (\%2.43) şeklindedir. Bir değer olarak fairplay kavramsal kategorisi ile ilgili kullanılan metaforlar ve gerekçelerine yönelik katılımcılar tarafından kullanılan bazı ifadeler aşağıda sunulmuştur:

Fairplay saygı gibidir çünkü...

"Kurallara, mücadele ettiğiniz takıma ve sporcuya saygı göstermek sporun özüdür, eğer bu değere sahip değilseniz iyi sporcu da olamazsınız.” (E/Sporcu)

“Saygının olmadığı ortamda alınan puanın, kazanılan maçın değeri yoktur.” (E/Öğretim Elemanı)

Fairplay erdem gibidir çünkü... 
“Her koşulda her türlü sonucu kabul edebilme erdemini gerektirir.” (E/Diğer)

"Fairplay benim için erdemli olmak gibi, zorunda olduğun için değil insanca yapılan bir tercih olduğu için." (K/Antrenör)

Fairplay nezaket gibidir çünkü...

“İyi olandan ve doğrudan ayrılmadan karşıdakine nezaket göstermeyi içerir.” (E/Antrenör)

Fairplay iyi niyet gidir çünkü...

“Tüm insanlara nasıl iyi niyet içinde yaşanılabileceğine yönelik örnekler sunar.” (E/ Öğretim Elemanı)

"Her şeyden önce insanca yaşamak için sahip olunması gereken iyi niyetin yapılan spora ve yer alınan karşılaşmaya aktarılmasıdır.” (K/Öğrenci)

Sosyal etkileşim olarak fairplay kavramsal kategorisinde katılımcıların \% 34.1'ine ait metafor bulunmaktadır. Bu katılımcıların \% 78'i erkek, \% 22'si kadındır. Dostluk (\% 42.34), yaşam (\% 13.14), birlik (\% 11.68), aile (\% 6.57), barış (\% 6.57), dayanışma (\% 6.57), paylaşım (\% 5.83), meydan okuma (\% 3.65) ve yansıtmak (\% 3.65) bu kategori çatısı altında geliştirilen metaforlardır. Fairplay kavramını bir sosyal etkileşim olarak algılayan katılımcıların ortaya koydukları gerekçelerden bazıları aşağıda belirtilmiştir:

Fairplay dostluk gibidir çünkü...

"Bir sporcu, takım ya da ülkenin müsabakayı kazanmasının ötesinde sporun kaynaştırıcı özelliği olan dostluğu kazanması için fairplay önem arz eder.” (K/Öğretim Elemanı)

“Çünkü gerçek arkadaşlar zor günde de arkadaşlarına sahip çıkar, gerçek sporcular da fairplaye.” (E/Antrenör)

Fairplay yaşam gibidir çünkü...

"İyi insan olmak için yaşamda sevgi ve saygıya, iyi sporcu olmak için de fairplaye sahip olmak gerekir. Sporun yazılı olmayan kuralı gibi...” (E/Diğer)

"Hayatta gerçek anlamda doğruyu iyiyi güzeli bulmak önemlidir. Sporda da fairplay tarzı ilkelerle istenilen güzelliğe ulaşılır.” (E/Antrenör)

Bir diğer kavramsal kategori olan bir hak olarak fairplay kavramsal kategorisinde katılımcıların \% 25.1'ine ait metafor bulunmaktadır. Bu katılımcıların \% 55'i erkek, \% 45'i kadındır. Geliştirilen metaforlar kural (\%58.43), adalet (\%16.83), kanun (\%12.87), eşitlik (\%6.93) ve bağımsızlık (\% 5.94) şeklindedir. Fairplay kavramını bir hak olarak ifade eden katılımcıların kullandıkları metaforlar ve gerekçeleri şu şekilde sıralanabilir:

Fairplay kural gibidir çünkü...

"Fairplayi korumak, hâkim kılmak ve desteklemek çok önemlidir. Böylece, gerçek şampiyonlar taçlandırılır, hile yapanlar değil." (K/Sporcu)

“Kurallar karşısında herkes eşittir. Fairplay de yazılı olmayan bir kural gibi bu eşitliği sağlar” (E/Antrenör)

Fairplay adalet gibidir çünkü...

“Çünkü adalet herkesin hakkını korur." (E/Öğretim Elemanı)

“Adalete bağlı kalmak hayatı, fairplay de oyunu iyileştirir.” (E/Öğrenci) 


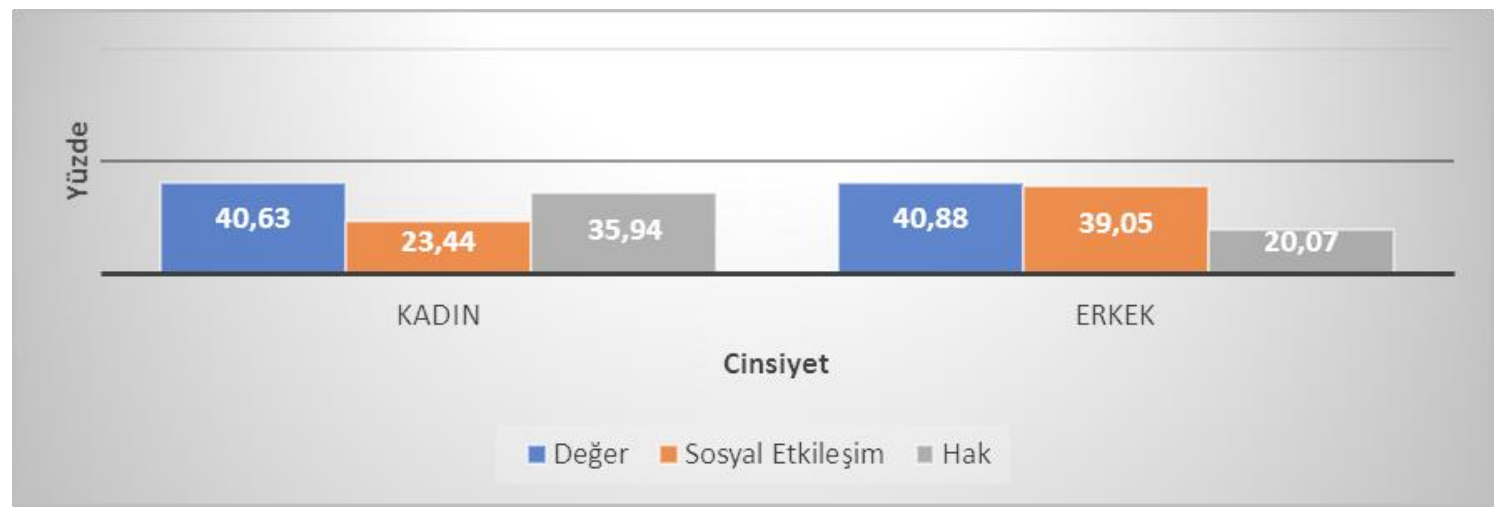

Grafik 2. Cinsiyetlere göre kavramsal kategorilerin kullanımı.

Grafik 2 cinsiyetlere göre kavramsal kategorilerin yüzdelik değerlerini göstermektedir. Erkek ve kadın katılımcıların en çok tercih ettikleri kavramsal kategori “değer"dir. Kadın katılımcılar "hak” kavramsal kategorisine ilişkin metaforları (35.07) erkek katılımcılardan daha fazla kullanmışlardır. Hak kavramsal kategorisi erkekler tarafından daha az tercih edilmiş olduğu görülmektedir (\%20.07). Kadınların ise en az tercih ettikleri kavramsal kategori “sosyal etkileşim”dir.

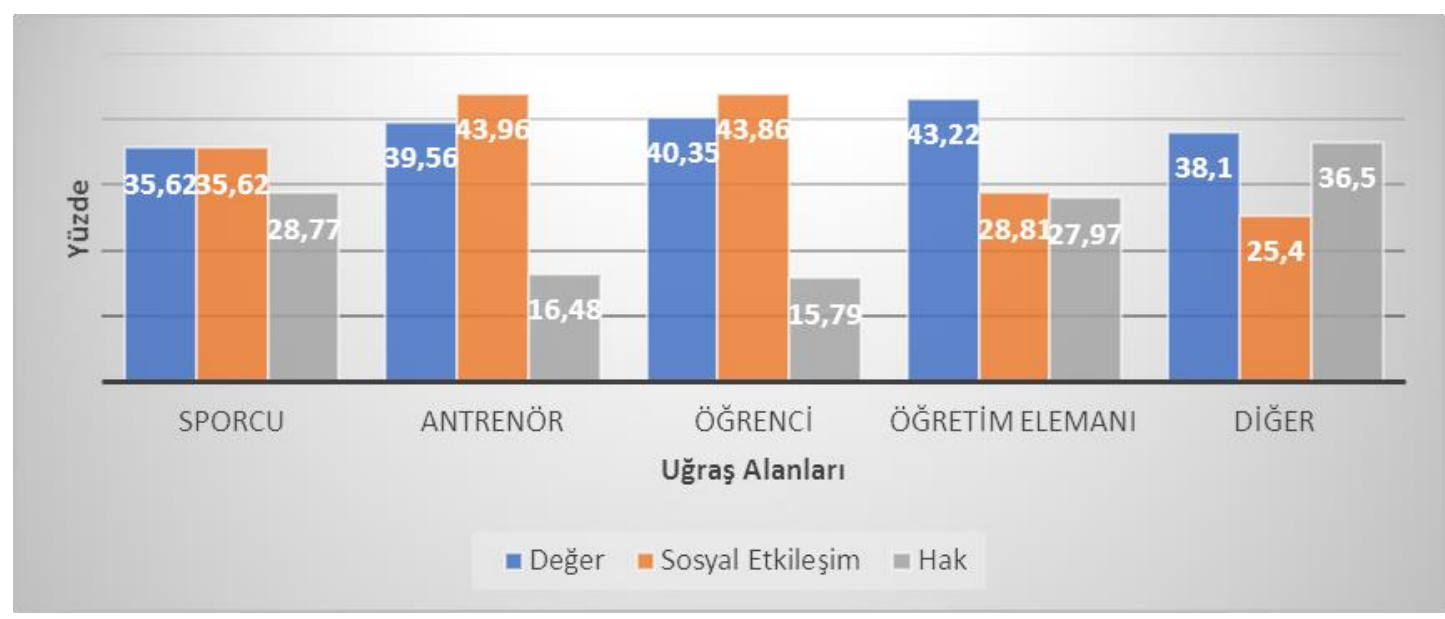

Grafik 3. Uğraşı alanlarına göre kavramsal kategorilerin kullanımı.

Katılımcıların uğraşı alanlarına göre kullandıkları metaforların yer aldıkları kavramsal kategoriler incelendiğinde sporcu, antrenör ve öğrencilerin kullandıkları metaforların daha çok sosyal etkileşim kavramsal kategorisi kapsamında yer aldığı görülmektedir.

Öğretim elemanları ve diğer grubunda yer alan uğraşı alanlarında yer alan katılımcıların ise fairplay kavramını bir değer olarak ele aldıkları görülmektedir. Burada araştırma sonucunda elde edilen bulgular yer almalıdır. Tablolar ve şekiller örneklerde gösterildiği gibi verilmelidir.

\section{TARTIŞMA, SONUÇ VE ÖNERILER}

Spor paydaşlarının fairplay ifadesini kavramsallaştırmak için ürettikleri metaforların neler olduğunu belirlemeye çalıştığımız bu araştırmada üç kavramsal kategori ortaya çıkmıştır: "Bir değer olarak fairplay”, "sosyal etkileşim olarak fairplay" ve "bir hak olarak fairplay".

Bir değer olarak fairplay, kategorisine bakıldığında bunların erdem, saygı, nezaket, iyi niyet, dürüstlük, insanlık, ahlak, onur ve hoşgörü kavramlarından oluştuğu görülmüştür. "Erdem” ve "saygı" bu kategoride en çok kullanılan 
kavramlardır. Araştırmamızda fairplay ifadesinin en çok "erdemlilik", "erdemli olma" gibi kavramlara benzetiliyor olması, bu ifadenin toplumumuzda "erdemli olmak" ile kavramsallaşmasını sağlayabilir. Bu sonuç, Boixados ve Cruz (1995) un fairplay tutum ölçeğinde taşıdığı öğeler ile doğrudan örtüşmektedir. Aynı şekilde fairplay ifadesinin kavramsallaştırılmasında ikinci sırada yer alan “saygı” kavramı da Boixados ve Cruz’un çalışmasıyla benzerlik göstermektedir. Metaforlar, düşünmek, konuşmak, eylemde bulunmak için ihtiyaç duyduğumuz kavramsal araçlar olarak kabul edilse de Nerlich, Craig ve Rowe (2002) metaforların dünyayı anlamayı kolaylaştıran kültürel ve sosyal araçlar olduklarını vurgular. Fairplay ifadesinin kavramsallaştığı bir diğer kategori de sosyal etkileşimdir. Katılımcılar fairplay ifadesi ile en çok “dostluk” kavramını oluşturmuşlardır. Yaşam, birlik, aile, barış, dayanışma, paylaşım, meydan okuma, yansıtma gibi kavramları kullanan katılımcıların oranı ise düşüktür. Spander ve arkadaşları (2014) "metaforların psikososyal açıdan uyum sorunu yaşayan bireylere destek amaçlı olarak kullanabileceğinden” söz ederken, Kellett (2002), antrenör ve sporcuların etkileşimi ile ilgili çalışmalarında, bir sosyalleşme aracı olarak metaforların kullanılabileceğini söyler. Bu yönleriyle bakıldığında fairplay ifadesine ilişkin bu çalışmadaki katılımcıların, sosyalleşmeye yönelik kavramlar üretmeleri ilgili alanyazını destekler niteliktedir. Aynı zamanda metaforların özünde sosyallik olan spora ilişkin kavramları açıklama ve anlamlandırmadaki kolaylaştırıcı rolünün önemini pekiştirmektedir.

Araştırmamızda katılımcıların fairplay ifadesine yönelik ürettikleri kavramların yer aldığı bir diğer kategori de "hak olarak fairplay"dir. Burada katılımcıların en çok "kural” kavramını kullandıkları görülmüştür. Sonra sırasıyla, adalet, kanun, eşitlik ve bağımsızlık kavramları gelmektedir. Fairplay ifadesi ile katılımcılar, fairplay davranışına sahip olan kişilerin hile ile değil gerçek mücadele ile şampiyonluklarını taçlandırabileceğini, fairplayin yazılı olmayan kurallar gibi herkesi eşitlik çizgisinde buluşturduğunu, adalet gibi herkesin hakkını koruduğunu belirtmişlerdir. Bu çalışma ile ortaya çıkan kavramlar, alanyazında fairplay ile ilgili yapılmış bir çok çalışmayla desteklenmektedir (Miller, Roberts ve Ommundsen, 2003; Ommundsen, Roberts, Lemyre ve Treasure, 2003; Spander ve diğ., 2014; Gibson ve Zellmer-Bruhn, 2001; Cruz, Boixad'os, Valiente ve Torregrosa, 2001).

Takada, Shinohara, Morizumi ve Sato (2002) kullanılan her bir metaforu sosyo-kültürel birikimin bir ürünü olarak değerlendirmekte ve bireylerin kullandıkları metaforları niçin tercih ettiklerini anlamanın yolunun onların sosyal ve kültürel arka planlarını incelemekten geçtiğini savunmaktadırlar.

Toplumsal cinsiyet düzeni kadın ve erkek arasındaki biyolojik farkın yarattı̆̆ı erkek üstünlüğü vurgulamaktadır. Cinsiyetler arası biyolojik farkı temel alan bu bakış açısı kadını erkek karşısında “öteki” olarak tanımlar. Erkek sporunun atletik performansın doğal yansıması olarak kabul edilmesi kadının spor alanında öteki başka bir ifadeyle ikincil olarak konumlandırılmasına neden olmaktadır (Koca, 2006). Katılımcıların cinsiyetlerine göre fairplay ifadesi ile ilgili ürettikleri kavramlar her iki cinsiyette de "değer" kavramında kümelenmiş olsa da erkekler fairplay ifadelerinde sosyalleşme ile ilgili daha çok kavram üretmiş, kadınlar çoğunlukla bir "hak" olarak fairplay kategorisine odaklanmışlardır. Türkiye'de Toplumsal Cinsiyet Eşitliğinin İzlenmesi Projesi (Koca, 2018) kapsamında yapılan analizde de kadın sporcuların medyada erkeklerden daha az temsil edildiği belirtilmektedir. Spor medyasında çıkan haberlerde kadınların sportif performansından ziyade daha çok toplumsal rollerine (anne, eş vb.) yer verildiği ve kadınların pasif konumlarına atıfta bulunulduğu görülmektedir. Bunun tersine erkeğin toplumsal statüsünün önemi ve sportif performansındaki başarıları ön plana çıkarılmaktadır (Bakan, 2013; Büyükafşar, 2016; Öktem, 2004). Kadın katılımcıların hak vurgusu erkek egemen spor kültürü nedeniyle ötekileştirilen kadınların toplumca yeteri kadar önemsenmeyen emek ve çabalarını görünür kılma isteği olabilir. Toplumsal cinsiyet rollerinin dönüşümüyle ilgili hareketler kadınların daha önce sahip olmadığ birçok hakka sahip olmasının yolunu açmıştır (Yüksel, 2014). Bu bağlamda kadın katılımcıların spora ilişkin fairplay kavramını neden daha çok hak kategorisine ilişkin metaforlarla açıklamaya çalıştıkları anlaşılabilir. Cinsiyetler arasındaki farklı 
metafor kullanımı Türk toplumunda kadın ve erkeklerin sosyo-kültürel açıdan çok farklı konumlandırıldıklarının da bir göstergesi olarak kabul edilebilir. Katılımcılar, uğraşı alanlarına göre fairplay ifadesine yönelik kavramsallaştırmayı tüm uğraşı alanlarında "değer" kategorisinde yapmışlardır. Sadece antrenör ve öğrencilerin sosyalleşme kategorisinde fairplay ifadesi ile ilgili kavramları daha çok ürettikleri görülmüştür. Sporcu ve öğretim elemanı grubunda bulunan katılımcıların fairplay ifadesi ile ilgili kavramsallaştırmada "hak" ile ilgili daha çok kavram ürettikleri belirlenmiştir. Hareket ve spor kültürü kapsamında yapılmakta olan etkinlikler mekanik eylemleri içerse de, onların belirleyicisi olan düşüncelerin yaşamdaki yansımaları da aynı oranda yoğun olabilmektedir. Düşünceler, duyguları tetikleyen önemli araçlardan birisidir. Düşünceleri oluşturan kavramlar onlara yüklenen anlamla şekillenebilmektedir. Spor paydaşları (antrenör, öğretim elemanı, sporcu, öğrenci, yönetici vs.) fairplay ifadesini spor ile ilgili her durumda karşılarında bulmaktadır. Bu ifadeleri duyduklarında, gördüklerinde üretebildikleri kavramlar ülkelerin spor kültürünün ortaya çıkarılabilmesi bakımından önem taşımaktadır. Toplumun diğer kesimlerinde aynı kavramla ilgili düşüncelerin oluşumunda bu araştırmadan çıkan sonuçlara göre çalışmalar yapılabilir. Bunun için spor paydaşlarının ilgili alan eğitimlerinde fairplay ifadesiyle üretilen kavramların içselleştirilebileceği etkinlikler bilişsel, duyuşsal ve psikomotor düzeyde yapılabilir. Sosyal etkileşim aracı olarak fairplay kavramına ilişkin üretilen kavramlara yönelik etkinlikler ve eğitimler düzenlenmesi önemli olabilir. Milli kimlik yanında, dünya insanı olabilecek ve bunları "vatandaşlık" kültürü ile bütünleştirebilecek "haklar" ile ilgili kavramların bireylere kazandırılmasında fairplay ifadelerine ilişkin kavramlar üzerinde durulmalıdır.

Metaforlar insanların günlük yaşamlarında kullandıkları kavramları ne şekilde anlamlandırdıklarını anlamamıza yardımcı olur (Saban, 2010). Bu açıdan bakıldığında; bu metafor çalışmasının, spor alanında yer alan paydaşların fairplay gibi sporla ilişkili bir kavramı nasıl içselleştirdikleri ve bu kavrama ne tür anlamlar yüklediklerinin ortaya çıkarılmasına katk1 sağladığı düşünülmektedir. Beden eğitimi ve spor öğretmenleri ve ayrıca küçük yaş gruplarıyla çalışmakta olan antrenörler öğrencilerin psikomotor, bilişsel ve duyuşşal gelişimini bir bütün olarak ele almalıdırlar (MEB, 2017). Bu bağlamda, küçük ve genç yaştaki öğrenci ve sporculara fairplay bilinci kazandırılması sürecinde kültürel ve sosyal engellerin ortadan kaldırılması ve fairplay kavramının etkili şekilde kazandııılmasında metaforların kolaylaştırıı bir faktör olarak kullanabileceği düşünülmektedir.

402 katılımcıyla tamamlanan bu çalışmanın daha fazla katılımcıyla gerçekleştirilmesi elde edilen verilerin güvenirliğinin arttırılmasına katkı sağlayabilir. Gelecek çalışmalar beden eğitimi ve sporla ilişkili diğer kavramlara yönelik olarak temel eğitimde yer alan öğrencileri kapsayacak şekilde bir araştırma tasarımı planlayabilir.

\section{KAYNAKLAR}

1. Alpar R. (2006). Spor bilimlerinde uygulamalı istatistik. Ankara: Nobel Yayın Dağıtım.

2. Bakan Ö. (2013). Türk medyasında kadın sporcuların temsili: Üç gazetenin içerik analizi. Selçuk İletişim Dergisi, 7(4), 129-139.

3. Boixadós M, Cruz J. (1995). Construction of a fairplay attitude scale in soccer. In R. Vanfraechem-Raway \& Y. Vanden Auweele (Eds.), Proceedings of the IX $X^{\text {th }}$ European Congress on Sport Psychology (pp. 4-11). Brusels: FEPSAC.

4. Büyükafşar, M. (2016). Türk Spor Basınında Cinsiyet Ayrımcılığı: Fotomaç ve Fanatik Gazeteleri Örneği. İnsan ve İnsan, 3(9).

5. Carley K. (1993). Coding choices for textual analysis. A comparison of content analysis and map analysis. Sociological Methodology, 23 , 75-126.

6. Clarke L. (2009). Football as a metaphor: Learning to cope with life, manage emotional illness and maintain health through to recovery. Journal of psychiatric and mental health nursing, 16, 488-492. http://dx.doi.org/10.1111/j.1365-2850.2009.01403.x

7. Creswell JW. (2003). Research design: Qualitative, quantitative, and mixed methods approaches. Thousand Oaks, CA: Sage.

8. Cruz J, Boixad'os M, Valiente L, Torregrosa M. (2001). Es perd el “fair play" i l'esportivitat a l'esport en edat escolar Is youth sport losing fairplay and sportpersonship? Apunts. Educaci'o F'isica i Esports, 64, 6-16. 
9. Duriau VJ, Reger RK, Pfarrer MD (2007). A content analysis of the content analysis literature in organization studies: Research themes, data sources, and methodological refinements. Organizational Research Methods, 10(1), 5-34. http://dx.doi.org/10.1177/1094428106289252

10. Gassner GJ. (1999). Using metaphors for high-performance teaching and coaching. Journal of Physical Education, Recreation \& Dance, 70(7), 33-35.

11. Grossman PL. (1990). The making of a teacher: Teacher knowledge and teacher education. Teachers College Press.

12. Hanin YL, Stambulova NB. (2002). Metaphoric description of performance states: An application of the IZOF model. The Sport Psychologist, 16(4), 396-415.

13. Hardcastle B, Yamamoto K, Parkay FW, Chan J. (1985). Metaphorical views of school: A cross cultural comparison of college students. Teaching and Teacher Education, 1, 309-315. http://dx.doi.org/10.1016/0742-051X(85)90019-8

14. Huff AS. (1990). Mapping strategic thought. Chichester, NY: John Wiley and Sons.

15. Kellett P. (2002). Football-as-war, coach-as-general: Analogy, metaphor and management implications. Football studies, 5(1), 60-76.

16. Koca C. (2006). Beden eğitimi ve spor alanında toplumsal cinsiyet ilişkileri. Hacettepe Spor Bilimleri Dergisi, 17(2), 81-99.

17. Koca C. (2018). Sporda toplumsal cinsiyet eşitliği haritalama ve izleme çalışması. Ankara: Ceid Yayınları.

18. Kövecses Z. (2002). Cognitive-linguistic comments on metaphor identification. Language and Literature, 11(1), 74-78.

19. Lakoff G, Johnson M. (1980). The metaphorical structure of the human conceptual system. Cognitive science, 4(2), 195-208.

20. Martínez MA, Sauleda N, Huber GL. (2001). Metaphors as blueprints of thinking about teaching and learning. Teaching and Teacher education, 17(8), 965-977.

21. MEB (Milli Ĕgitim Bakanlı̆̆ı). (2017). Beden eğitimi ve spor dersi öğretim programı. Mart 1, 2017, http://mufredat.meb.gov.tr

22. Miles MB, Huberman AM. (1994). Qualitative analysis. An expanded sourcebook.

23. Miller BW, Roberts GC. Ommundsen Y. (2003). Effect of motivational climate on sportpersonship among competitive youth male and female football players. Scandinavian Journal of Medicine \& Science in Sport, 13, 1-10.

24. Mojtabai R. (2000). Delusion as error: The history of a metaphor. History of Psychiatry, 11(41), 003-14.

25. Nerlich B, Craig AH, Rowe B. (2002). Conceptualising foot and mouth disease: the socio-cultural role of metaphors, frames and narratives. Metaphorik.de, 2, 90-108.

26. Ommundsen Y, Roberts GC, Lemyre PN, Treasure D. (2003). Perceived motivational climate in male youth soccer: Relations to social-moral functioning, sportpersonship and team norm perceptions. Psychology of Sport and Exercise, 4(4), 397-413.

27. Öktem, MG. (2004). Sporcu kadının Türk yazılı basınındaki temsili: Süreyya Ayhan örneği. Kadın Çalışmalarında Disiplinlerarası Buluşma, Yeditepe Üniversitesi, İstanbul.

28. Saban A. (2010). Prospective teachers' metaphorical conceptualizations of learner. Teaching and Teacher Education, 26(2), $290-305$.

29. Spander H, Roy A, Mckeown M. (2014). Using football metaphor to angage men in therapeutic support. Journal of Social Work Practice, 2(28), 229-245. http://dx.doi.org/10.1080/02650533.2013.853286

30. Takada, M., Shinohara, K., Morizumi, F., \& Sato, M. (2000). A study of metaphorical mapping involving socio-cultural values: how woman is conceptualized in Japanese. In Proceedings of the 14th Pacific Asia Conference on Language, Information and Computation (pp. 301-312).

31. Thornborrow J, Wareing, S. (1998). Patterns in language: An introduction to language and literary style. Psychology Press.

32. Triggs C, Lafferty ME, Brown HE, Tolley HL. (2011). Metaphorical use of song lyrics within sport psychology practice: Targeting the transition within a premier league football youth academy. Journal of Sport Psychology in Action, 2(3), 183-195. http://dx.doi.org/10.1080/21520704.2011.619046

33. Yıldırım A, Şimşek H. (2011). Sosyal bilimlerde nitel araştırma yöntemleri. Ankara: Seçkin Yayıncılık.

34. Yüksel M. (2014). Cinsiyet ve spor. Tarih Okulu Dergisi, 7(14), 663-684. 